\title{
Permainan Estafet untuk Meningkatkan Kemampuan Motorik Kasar Anak Usia 5-6 Tahun
}

\author{
Uswatun Hasanah Masra Tangse ${ }^{1}{ }^{\bowtie}$, Dimyati $^{2}$ \\ Pendidikan Anak Usia Dini, Universitas Negeri Yogyakarta(1) \\ Pendidikan Ilmu Keolahragaan, Universitas Negeri Yogyakarta, Indonesia(2) \\ DOI: $10.31004 /$ obsesi.v6i1.1166
}

\begin{abstract}
Abstrak
Bermain menjadi salah satu cara anak belajar dan meningkatkan kemampuannya. Melalui bermain membuat anak jadi sehat secara fisik maupun psikis, membantu pertumbuhan dan perkembangan anak khususnya kemampuan motorik kasar. Tujuan penelitian ini ialah untuk mengetahui keefektifan permainan estafet sebagai salah satu kegiatan yang menggunakan fisik motorik dalam meningkatkan kemampuan motorik kasar anak usia 5-6 tahun. Permainan estafet ini memiliki 4 kegiatan bermain yang didalamnya terdapat kegiatan yang mengandung unsur motorik kasar. Penelitian ini menggunakan metode quasiexperiment dengan one group pretest-posttest design, dan melibatkan 15 anak disalah satu TK di Kabupaten Labuhanbatu Selatan pada bulan September 2020. Hasil penelitian ini menunjukkan bahwa terdapat pengaruh penggunaan permainan estafet terhadap kemampuan motorik kasar anak usia 5-6 tahun. Kegiatan permainan estafet ini juga dapat menjadi salah satu acuan kegiatan pembelajaran dalam meningkatkan kemampuan motorik kasar anak di sekolah maupun diluar sekolah.
\end{abstract}

Kata Kunci: anak usia dini; motorik kasar; permainan estafet.

\begin{abstract}
Playing is one way for chlidren to learn and improve their abilities. Through playing, it makes children physically and psychologically healthy, helps the growth and development of children, especialy gross motor skills. The purpose of this study was to determine the effectiveness of relay games as an activity that uses physical motor skills to improve gross motor skills of children aged 5-6 years. This relay game has 4 playing activities in which there are activities that contain gross motoric elements. This study used a quasi-experimental method with one group pretest-posttest design, and involved 15 children in one kindergarten in Kabupaten Labuhanbatu Selatan. The results of this study indicate that there is an effect of the use of relay games on gross motor skills of children aged 5-6 years. This relay game activity can also be reference of learning activities in improving children's gross motor skills at school and outside of school.
\end{abstract}

Keywords: early childhood; relay game; gross motor skills.

Copyright (c) 2021 Uswatun Hasanah Masra Tangse, Dimyati

$\triangle$ Corresponding author:

Email Address : uswatun25pasca.2018@student.uny.ac.id (Yogyakarta, Indonesia)

Received 26 February 2021, Accepted 19 March 2021, Published 21 March 2021 


\section{PENDAHULUAN}

Aktivitas fisik pada tahun awal pertumbuhan anak-anak merupakan sebuah keterampilan yang dibutuhkan untuk memiliki gaya hidup sehat di masa yang akan datang (Tandon et al., 2020). Seperti yang diketahui sebagian besar aktivitas anak memerlukan kemampuan motorik, lingkungan aktivitas fisik dan peluang untuk melakukan aktivitas fisik di masa pertumbuhan anak menjadi sebuah peluang yang cukup besar bagi kesehatan anak dan pembelajaran dini (Story et al., 2006). Perkembangan anak usia dini berjalan dengan cepat, hal ini dikarenakan sel-sel saraf berkembang mengikuti pengalaman anak. Semakin anak memiliki banyak pengalaman, maka semakin besar potensi anak untuk memasuki dunia baru (Masnipal, 2018). Pendidikan anak usia dini pada dasarnya meliputi upaya dalam pemberian stimulasi dan asuhan dalam kegiatan pembelajaran yang akan menghasilkan kemampuan dan keterampilan anak. Pengalaman belajar selama masa perkembangan ini diperoleh anak dengan cara mengamati, meniru dan melakukan eksperimen secara langsung yang melibatkan seluruh potensi dan kemampuan anak (M. Fadlilah, 2014). Salah satu aspek yang sangat penting untuk distimulasi pada anak yaitu aspek kemampuan motorik kasar. Pentingnya meningkatkan kemampuan motorik kasar anak dikarenakan motorik kasar merupakan satu kemampuan yang membantu anak dalam melakukan aktivitas sehari-hari seperti meloncat, berlari, berjalan serta berdiri dengan satu kaki (Bambang, 2008).

Masalah yang selalu berkaitan dengan motorik kasar yaitu obesitas yang sering terjadi dikarenakan kurangnya kegiatan fisik yang dilakukan oleh anak. Menurut Data Riset Kesehatan Dasar (2013) kondisi anak Indonesia sebanyak 8 dari 10 anak mengalami obesitas. Padahal dibandingkan dengan anak dengan berat badan normal, anak yang mengalami obesitas dan kelebihan berat badan lebih cenderung mengalami keterlambatan perkembangan fisik motorik (Abdelgawad \& Mohamed, 2018). Pada sebuah studi yang dipresentasikan pada Konferensi American College of Caridology's yang dikutip dari CNN Indonesia (Fajrina, 2015) menemukan, anak-anak yang menghabiskan waktu bersama gadget lebih rentan mengalami kenaikan berat badan dan obesitas karena kurangnya gerak tubuh. Anak-anak yang mengalami obesitas menunjukkan tingkat aktivitas fisik yang rendah dibandingkan anak dengan berat badang yang normal (Morrison et al., 2018). Oleh karena itu, untuk mengatasi permasalahn dalam kurangnya aktivitas pada tubuh anak diperlukan kegiatan yang memerlukan aktivitas gerak. Aktivitas gerak yang menyenangkan dan biasa dilakukan anak ialah kegiatan bermain. Sesuai dengan pernyataan (Fjørtoft, 2004) yang mengatakan bahwa bermain dapat meningkatkan perkembangan motorik.

Bermain merupakan kegiatan yang sangat penting untuk pertumbuhan dan perkembangan anak karena bermain menjadi sumber belajar yang tidak diperoleh anak di sekolah maupun dirumah (Mutiah, 2010). Melalui bermain, anak-anak tidak hanya meningkatkan dan mencapai aspek perkembangan yang lebih baik atas kemampuan motorik, tetapi juga dapat membangun kepercayaan diri anak, dan belajar bagaimana menangani rintangan yang sulit (Serpentino, 2011). Bermain diluar ruangan dapat dianggap sebagai salah satu cara untuk membuat anak-anak lebih sehat dan aktif secara fisik (Fjørtoft, 2004; Lovasi et al., 2011). Sedangkan Hu et al. (2015) juga sependapat dengan menyatakan bermain bebas di lingkungan luar adalah cara terbaik untuk mempromosikan perkembangan fisik ketika anakanak dibimbing untuk secara bebas bisa mengakses berbagai aktivitas yang menantang fisik. Lingkungan luar bukanlah lingkungan yang asing untuk anak. Dengan aktif bermain bebas di lapangan merupakan sebuah kesempatan penting bagi anak untuk meningkatkan kemampuan aktivitas fisik mereka dan gaya hidup sehat (Caroli et al., 2011)

Perkembangan motorik kasar merupakan kemampuan yang meliputi kegiatan otototot besar, seperti berjalan, melompat, berlari dan menggerakkan lengan (Santrock, 2007). Kemampuan motorik kasar merupakan bagian dari aspek keseimbangan, kekuatan, kelenturan, kecepatan, kelincahan, yang menjadi sebuah pemicu salah satu aktivitas olahraga, atau kegiatan yang melatih fisik (Veldman et al., 2016). Bentuk kegiatan bermain yang dapat meningkatkan kemampuan motorik kasar haruslah mengandung kegiatan seperti berlari, 
berjalan, atau melompat yang membutuhkan otot-otot besar. Permainan menjadi salah satu sarana dalam meningkatkan kemampuan motorik kasar anak. Permainan adalah suatu alat yang digunakan oleh anak-anak untuk menjelajahi dan mencari informasi baru yang dimana tidak anak temukan jika tidak adanya suatu permainan (Andini, 2018). Salah satu kegiatan permainan yang dilakukan melibatkan kemampuan fisik dan motorik yaitu permainan estafet. Permainan estafet merupakan permainan yang dilakukan secara beregu, dimana setiap regu terdiri dari empat orang pelari, dan setiap pelari mempunyai peran masingmasing dalam permainan (Sunarsih \& Dkk., 2007). Dalam penelitian ini permainan estafet ialah suatu permainan yang didalamnya terdapat beberapa kegiatan yang berbeda, yang harus diselesaikan secara berurutan oleh masing-masing anggota kelompok sambil membawa tongkat estafet. Anak saling memberi tongkat estafet setelah menyelesaikan semua rintangan yang ada dalam permainan. Kegiatan bermain ini menciptakan suasana yang menyenangkan sekaligus menantang bagi anak.

Dalam penelitian ini permainan estafet dilaksanakan diluar ruangan. Bermain permainan estafet ini tediri dari beberapa langkah pelaksanaan yaitu: (a) membagi anak dalam beberapa kelompok yang terdiri dari 3-5 orang; (b) setiap anak harus melakukan 4 kegiatan yang telah dibagi menjadi 4 pos bermain yaitu meloncat sesuai arah yang diinstruksikan, berlari sesuai pola yang ditandai dengan botol plastik, berlari memindahkan bola ke dalam keranjang secara bolak-balik, dan berjalan diatas papan titian; (c) anak wajib menyelesaikan semua kegiatan bermain yang ada pada setiap pos bermain sambil membawa tongkat estafet; (d) setelah semua pos terlewati, anak yang membawa tongkat memberikan tongkat estafet tersebut kepada anak berikutnya yang menunggu digaris start; (e) semua anak wajib melewati setiap pos untuk sampai ke garis finish. Setelah semua kegiatan selesai dilakukan kelompok yang paling cepat menyelesaikan rintangan akan mendapatkan reward. Sehingga dalam permainan estafet ini akan tercipta suasana yang menyenangkan dan tertantang. Permainan estafet ini belum pernah dilakukan oleh sekolah yang penulis teliti. Permainan yang biasa digunakan di sekolah ini untuk mengembangkan motorik kasar pada anak didik yaitu kegiatan permainan tradisional seperti bermain engklek, congklak, lompat tali, dll. Dan senam pagi yang akan dilakukan rutin sebelum memasuki ruangan kelas.

Berdasarkan fakta yang terdapat di lapangan dan beberapa hasil penelitian sebelumnya, maka perlu adanya peningkatan kemampuan motorik kasar anak dalam sebuah permainan atau kegiatan bermain yang menyenangkan. Oleh karena itu, peneliti mencoba melakukan penelitian untuk meningkatkan kemampuan motorik kasar anak melalui permainan estafet karena permainan estafet ini belum pernah dilakukan di sekolah yang akan peneliti laksanakan sehingga kegiatan ini diharapkan menjadi solusi untuk para guru dalam meningkatkan kemampuan motorik kasar anak dan juga sebagai bahan pembelajaran.

\section{METODOLOGI}

Penelitian ini menggunakan one group pretest-posttest design, desain penelitian ini menggunakan pretest sebelum diberi perlakuan sehingga dapat membandingkan dengan posttest sesudah diberikannya perlakuan (Sugiyono, 2019). Pelaksanaan penelitian dilakukan pada bulan September 2020 yang melibatkan subjek penelitian sebanyak N = 15 pada rentang usia 5-6 tahun di salah satu Taman Kanak-Kanak Kecamatan Silangkitang, Labuhanbatu Selatan yang berpartisipasi dalam permainan estafet untuk meningkatkan kemampuan motorik kasar pada anak. Teknik dan instrumen yang digunakan dalam pengumpulan data menggunakan test dan observasi. Gambar 1 skema desain one group pretest-posttest design.

$\begin{array}{cc}\text { Pretest }\left(\mathrm{O}_{1}\right) & \text { Posttest }\left(\mathrm{O}_{2}\right) \\ \bullet & \bullet\end{array}$

Gambar 1. Skema desain one group pretest-posttest 
Perlakuan yang diberikan kepada anak dalam penelitian ini yaitu permainan estafet yang dilakukan diluar ruangan. Berdasarkan observasi sebelumnya anak kurang melakukan aktivitas fisik diluar ruangan. Pada permainan estafet terdapat 4 permainan modifikasi yang didalamnya memuat aspek motorik kasar. Kegiatan bermain tersebut yaitu berlari meloncat sesuai arah, berlari zig-zag, memindahkan bola secara bolak-balik, dan berjalan diatas papan titian. Dalam permainan estafet ini anak diharuskan menyelesaikan semua rintangan permainan dari garis start sampai dengan finish sambil membawa tongkat estafet kemudian memberikan tongkat tersebut kepada pemain selanjutnya.

Rangkaian prosedur penelitian pada penelitian ini yaitu melakukan pretest untuk mengetahui tingkat kemampuan motorik kasar anak usia 5-6 tahun. Kemudian anak diberikan perlakuan berupa kegiatan permainan estafet yang memiliki 4 kegiatan bermain. Setelah diberikan perlakuan kepada anak maka dilakukan posttest untuk mengetahui pengaruh permainan estafet terhadap kemampuan motorik kasar anak usia 5-6 tahun. Teknik pengumpulan data pada penelitian ini menggunakan observasi dan test yang dilakukan kepada anak. Data yang didapatkan kemudian dianalisis secara kuantitatif untuk mengetahui perbandingan hasil perlakuan yang diberikan kepada anak.

\section{HASIL DAN PEMBAHASAN}

Setelah memberikan perlakuan pada anak di penelitian ini, maka diperoleh berbagai hasil dan pembahasan berkaitan dengan model permainan estafet dalam meningkatkan kemampuan motorik kasar anak usia 5-6 tahun. Pada penelitian ini, peneliti melakukan uji normalitas, uji homogenitas dan uji hipotesis. Penggunaan data dalam penelitian ini dianalisis menggunakan SPSS 22.0 untuk mengetahui apakah terdapat perbedaan rata-rata pretest dan posttest. Asumsi hipotesis yang perlu dilihat dalam penelitian ini yaitu jikan nilai sig. (2-tailed) $<0,05$, maka terdapat perbedaan yang signifikan antara motorik kasar pada data pretest dan posttest. Tetapi, jika sig. (2-tailed) >0,05 maka tidak terdapat perbedaan yang signifikan antara motorik kasar pada data pretest dan posttest. Tabel 1 adalah data hasil pretest dan posttest pada penelitian ini.

Tabel 1. Data Hasil Pretest Posttest

\begin{tabular}{ccc}
\hline \multirow{2}{*}{ Hasil } & \multicolumn{2}{c}{ Motori Kasar } \\
& Pretest & Posttest \\
\hline Jumlah & 15 & 15 \\
Anak & & \\
Nilai & 5 & 14 \\
Terendah & & \\
Nilai & 11 & 16 \\
Tertinggi & & \\
$\quad$ Skor & $\mathbf{1 1 3}$ & $\mathbf{2 2 9}$ \\
Rata-Rata & $\mathbf{7 , 5 3}$ & $\mathbf{1 5 , 2 6}$ \\
\hline
\end{tabular}

Tabel 2. Perbandingan data Pretest dan Posttest

\begin{tabular}{ccccccc}
$\begin{array}{c}\text { No. } \\
\text { Anak }\end{array}$ & Pretest & Posttest & & $\begin{array}{c}\text { No. } \\
\text { Anak }\end{array}$ & Pretest & Posttest \\
\cline { 1 - 2 } \cline { 5 - 7 } & 8 & 15 & & 9 & 5 & 15 \\
2 & 9 & 14 & & 10 & 7 & 15 \\
3 & 8 & 16 & & 11 & 8 & 15 \\
4 & 8 & 16 & & 12 & 6 & 15 \\
5 & 7 & 16 & & 13 & 8 & 16 \\
6 & 11 & 16 & & 14 & 7 & 15 \\
7 & 8 & 14 & & 15 & 6 & 16 \\
8 & 7 & 15 & & $\begin{array}{c}\text { Rata- } \\
\text { rata }\end{array}$ & 7,53 & 15,26 \\
& & & & & \\
\hline
\end{tabular}

Pada tabel 1, nilai pretest didapatkan melalui observasi di TK B pada anak usia 5-6 tahun yang berjumlah sebanyak 15 anak. Setelah nilai pretest didapatkan, model permainan estafet kemudian di aplikasikan sebanyak 6 kali treatment selama 2 minggu pemberian treatment. Setelah pemberian treatment, kemudian didapatkan nilai posttest terhadap ke 15 anak di TK B. Tabel 2 adalah perbandingan data pretest dan posttest dalam penelitian ini.

Berdasarkan tabel 2, dapat dilihat nilai rata-rata pretest pada anak usia 5-6 tahun sebesar 7,53, kemudian setelah diberikan perlakuan permainan estafet meningkat mencapai rata-rata posttest sebesar 15,26. Analisis data kuantitatif pada hal ini dapat disimpulkan bahwa adanya perbedaan yang signifikan antara motorik kasar pada data pretest dan posttest penerapan permainan estafet. Penelitian ini menggunakan uji hipotesis dan uji asumsi berupa

12 | Jurnal Obsesi : Jurnal Pendidikan Anak Usia Dini, 6(1) 2022 
DOI: 10.31004/obsesi.v6i1.1166

uji normalitas dan uji homogenitas sebagai salah satu acuan dalam penggunaan analisis uji-t. Berikut hasil uji prasyarat yang akan peneliti paparkan.

\section{Uji Normalitas}

Uji normalitas digunakan untuk mengetahui nilai residual yang diteliti berdistribusi normal atau tidak. Pengujian ini menggunakan uji normalitas Kolmogorov-Smirnov. Hasil dari uji normalitas dapat dilihat pada tabel 3.

Tabel 3. Uji Normalitas Kolmogorov-Smirnov One-Sample Kolmogorov-Smirnov Test

\begin{tabular}{|l|l|r|}
\hline \multicolumn{2}{|c|}{} & \multicolumn{2}{|c|}{ Unstandardized Residual } \\
\hline $\mathrm{N}$ & 15 \\
Normal & Mean & .0000000 \\
Parametersa,b & Std. Deviation & .70235573 \\
Most Extreme & Absolute & .213 \\
Differences & Positive & .205 \\
& Negative & -.213 \\
Test Statistic & & .213 \\
\multicolumn{2}{l|}{ Asymp. Sig. (2-tailed) } & $.065 \mathrm{c}$ \\
\hline
\end{tabular}

a. Test distribution is Normal.

b. Calculated from data.

c. Lilliefors Significance Correction.

Untuk pengambilan kesimpulan jika nilai sig. $>0,05$ maka nilai residual berdistribusi normal. Sedangkan jika nilai sig. $<0,05$ maka nilai residual berdisribusi tidak normal. Berdasarkan tabel diatas dapat dilihat bahwa nilai sig. 0,065 dan lebih besar dari 0,05 sesuai dengan asumsi yang telah dijabarkan, maka nilai residual berdistribusi normal.

\section{Uji Homogenitas}

Pengujian ini digunakan untuk meyakinkan bahwa kelompok data memang berasal dari populasi yang memiliki varians yang sama (homogen). Hasil uji homogenitas dapat dilihat pada tabel 4.

\begin{tabular}{|c|c|c|c|}
\hline $\begin{array}{r}\text { Tak } \\
\text { Test of }\end{array}$ & $\begin{array}{l}\text { Uji Ho } \\
\text { nogeneit } \\
\text { TORIK K }\end{array}$ & $\begin{array}{l}\text { genitas } \\
\text { Varianc } \\
\mathrm{AR}\end{array}$ & \\
\hline Levene Statistic & df1 & $\mathrm{df2}$ & Sig. \\
\hline 3.060 & 1 & 28 & .091 \\
\hline
\end{tabular}

Dasar pengambilan kesimpulan jika nilai sig. > 0,05 maka distribusi data homogen. Sedangkan jika nilai sig. $<0,05$ maka distribusi data tidak homogen. Berdasarkan tabel diatas dapat dilihat bahwa nilai sig. 0,091 dan lebih besar dari 0,05 sesuai dengan asumsi yang telah dijabarkan, maka kelompok data sampel memiliki varians yang sama (homogen).

\section{Uji Hipotesis}

Uji hipotesis digunakan untuk mengetahui perkembangan motorik kasar anak usia 56 tahun setelah diberikan perlakuan permainan estafet, maka perlu dilihat hubungan atau perbedaan data pretest dan posttest dengan menggunakan uji paired sample T-test. Tabel 5 adalah hasil Uji hipotesis paired sample test.

Dasar pengambilan keputusan jika nilai sig. < 0,05 maka adanya perbedaan yang signifikan antara data pretest dan data posttest. Sedangkan jika nilai sig. $>0,05$ maka tidak adanya perbedaan yang signifikan antara pretest dan posttest. Berdasarkan tabel diatas dapat dilihat bahwa nilai sig. (2-tailed) sebesar 0,000 yang artinya sig. $<0,05$, maka dapat disimpulkan bahwa terdapat perbedaan yang signifikan antara hasil pretest dan posttest. Ini 
menunjukkan terdapat pengaruh yang bermakna terhadap perbedaan perlakuan yang diberikan pada masing-masing variabel.

Tabel 5. Uji Hipotesis Paired Samples Test Paired Samples Test

\begin{tabular}{|c|c|c|c|c|c|c|c|c|c|}
\hline & \multicolumn{5}{|c|}{ Paired Differences } & \multirow[b]{3}{*}{$\mathrm{t}$} & \multirow[b]{3}{*}{$\mathrm{df}$} & \multirow{3}{*}{$\begin{array}{c}\text { Sig. } \\
(2- \\
\text { tailed) }\end{array}$} \\
\hline & & \multirow[b]{2}{*}{ Mean } & \multirow{2}{*}{$\begin{array}{c}\text { Std. } \\
\text { Deviati } \\
\text { on }\end{array}$} & \multirow{2}{*}{$\begin{array}{l}\text { Std. } \\
\text { Error } \\
\text { Mean }\end{array}$} & \multicolumn{2}{|c|}{$\begin{array}{c}95 \% \text { Confidence Interval } \\
\text { of the Difference }\end{array}$} & & & \\
\hline & & & & & Lower & Upper & & & \\
\hline Pair 1 & $\begin{array}{l}\text { PRETEST - } \\
\text { POSTTEST }\end{array}$ & -7.733 & 1.534 & .396 & -8.583 & -6.884 & -19.528 & 14 & .000 \\
\hline
\end{tabular}

\section{Pembahasan}

Permainan estafet yang diteliti dalam penelitian ini berupa sebuah permainan yang dimana terdapat 4 kegiatan bermain yang bertujuan untuk meningkatkan kemampuan motorik kasar. Permainan estafet ini dirancang dengan semenarik mungkin sehingga anak dapat mengikuti permainan dengan senang dan tidak bosan. Dalam lingkungan sekolah, pendidik memberikan bimbingan dalam permainan, menggunakan permainan sebagai kegiatan belajar mengajar untuk memenuhi tujuan pembelajaran yang akan dicapai tanpa mengubah aspek penting dari sebuah permainan (Bodrova et al., 2013). Untuk mendapatkan pengalaman belajar, anak-anak perlu aktif secara fisik terhadap segala aktivitasnya, dan aktivitas fisik bawaan anak-anak adalah bermain. Bermain bertujuan meningkatkan aspekaspek penting dalam perkembangan anak khususnya kemampuan motorik kasar.

Pengembangan kemampuan motorik kasar di Taman Kanak-kanak pada dasarnya sangat identik dengan kegiatan pembelajaran melalui bermain, sehingga pemberian rangsangan hendaknya juga dilakukan melalui proses pembelajaran yang dirancang dengan menggunakan permainan agar dapat menciptakan kenyamanan dan kemudahan bagi anak usia dini (Lestari \& Ratnaningsih, 2016). Hal ini saling berhubungan dengan pernyataan Bodi \& Belajar (2019) yang menyatakan untuk mencapai tujuan pendidikan, pendidik perlu mengupayakan membangun suasana belajar yang menyenangkan dengan memperhatikan tujuan pembelajaran, langkah-langkah, materi dan media yang menarik sehingga anak dapat mengikuti pembelajaran dengan baik. Kemampuan motorik kasar ialah kemampuan yang meliputi kegiatan otot-otot besar, seperti berjalan dan menggerakkan lengan (Santrock, 2007). Kemampuan motorik kasar merupakan bagian dari keseimbangan, kekuatan, kelenturan, kecepatan, ketepatan, kelincahan, yang menjadi sebuah pemicu salah satu kegiatan olahraga, atau kegiatan yang melatih fisik. Pada penelitian ini hanya berfokus kepada aspek kekuatan, kelincahan dan keseimbangan motorik kasar anak.

Perkembangan motorik kasar anak akan semakin membaik apabila stimulasi yang diberikan juga tepat. Faigenbaum et al. (1999) menyatakan bahwa aktivitas fisik dapat menguatkan otot dan menjaga kesehatan dan kebugaran tubuh anak serta dapat mencegah obesitas. Tugas perkembangan anak yang paling penting dalam masa taman kanak-kanak dalam tahun permulaan saat anak masuk TK adalah mengembangkan motoriknya berdasarkan pengoordinasian kumpulan otot yang berbeda saat bergerak atau melakukan aktivitas. Dari hasil penelitian ini dapat dilihat aktivitas fisik yang dilakukan dengan berbagai gerakan dapat membantu meningkatkan kemampuan motorik kasar anak, terbukti dari peningkatan yang terjadi antara hasil pretest dan posttest anak. Hal ini didukung oleh penelitian sebelumnya yang dilakukan oleh Ramdani \& Azizah (2019) yang menyatakan bahwa aktivitas bermain dalam sebuah permainan dapat meningkatkan kemampuan motorik pada anak. Tak hanya itu, penelitian dari (Abdillah, 2019) menyatakan bahwa model pembelajaran berbasis permainan yang disusun dengan baik dapat meningkatkan kemampuan motorik anak. 
Hasil penelitian yang dilakukan memperlihatkan hasil yang signifikansi antara hasil kemampuan motorik kasar anak terhadap permainan estafet sebelum diberikan treatment dan sesudah diberikan treatment. Kemampuan motorik kasar anak meningkat yang dapat dilihat dari hasil rerata yang diperoleh anak. Hal ini disebabkan karena permainan estafet yang dilaksanakan pada penelitian ini dibuat sesuai dengan studi pendahuluan dan kemampuan motorik kasar anak usia 5-6 tahun. Permainan estafet dalam penelitian ini memiliki empat kegiatan bermain yang didalamnya mencakup beberapa aspek dari kemampuan motorik kasar yaitu kekuatan, kelincahan, dan keseimbangan. Kegiatan bermain yang terdapat dalam permainan estafet ini yaitu meloncat sesuai arah, memindahkan bola dengan berlari bolakbalik, berlari zig-zag yang ditandai dengan botol plastik dan berjalan diatas papan titian. Pembelajaran yang dilaksanakan dengan menggunakan permainan estafet dan dilakukan diluar ruangan dapat membantu anak mengekspresikan diri dan tindakan mereka secara bebas.

\section{SIMPULAN}

Permainan estafet efektif dan layak untuk digunakan pada kegiatan inti pelaksanaan kegiatan pembelajaran pada jenjang taman kanak-kanak, hal ini dikarenakan permainan estafet mengandung unsur aktivitas fisik yang dapat meningkatkan kemampuan motorik kasar pada anak usia 5-6 tahun. Pada saat anak melakukan permainan estafet, antusias anakanak menjadi lebih tinggi karena anak mendapatkan pengalaman baru yang menyenangkan ketika anak bermain. Permainan estafet tak hanya meningkatkan kemampuan motorik kasar anak tetapi juga mampu membantu anak secara signifikan untuk sabar dalam menunggu giliran.

\section{UCAPAN TERIMA KASIH}

Ucapan terimakasih peneliti sampaikan kepada anak-anak TK B dan pihak sekolah di TK Kabupaten Labuhanbatu Selatan yang telah bersedia membantu dan bekerjasama dalam penelitian ini, ucapan terimakasih juga peneliti sampaikan kepada Universitas Negeri Yogyakarta khususnya program pascasarjana dalam membantu dan mendukung penyelesaian artikel ini. Tak lupa peneliti sampaikan ucapan terimakasih kepada dosen pembimbing Bapak Prof. Dr. Dimyati, M.Si, yang telah membimbing penulis dalam penyelesaian artikel ini. Terakhir ucapan terimakasih kepada para tim editor jurnal Obsesi sehingga artikel ini dapat memungkinkan untuk diterbitkan.

\section{DAFTAR PUSTAKA}

Abdelgawad, H. A., \& Mohamed, M. M. (2018). Effect of Body Mass Index on Gross Motor Development in Normal Children Effect of Body Mass Index on Gross Motor Development in Normal Children. December 2017, 2-7.

Abdillah, A. (2019). Pengembangan Model Pembelajaran Motorik Berbasis Permainan. Jurnal Pendidikan Olahraga, 8(2), 138. https://doi.org/10.31571/jpo.v8i2.1446

Andini, P. (2018). Bermain dan Permainan Anak usia Dini. In A. Asmara (Ed.), Kencana (Vol. 1, p. 236). PT Remaja Rosdakarya.

Bambang, S. (2008). Metode Pengembangan Fisik. Jakarta: Universitas Terbuka.

Bodi, S. K., \& Belajar, H. (2019). Pengembangan Media Pembelajaran Sistem Kelistrikan Untuk Meningkatkan Hasil Belajar Pada Program. 13(01), 75-79.

Bodrova, E., Germeroth, C., \& Leong, D. J. (2013). Play and Self-Regulation: Lessons from Vygotsky. American Journal of Play, 6(1), 111-123. http://eric.ed.gov/?id=EJ1016167

Caroli, M., Malecka-Tendera, E., Epifani, S., Rollo, R., Sansolios, S., Matusik, P., \& Mikkelsen, B. E. (2011). Physical activity and play in kindergarten age children. International Journal of Pediatric Obesity, 6(SUPPL. 2), 47-53. https://doi.org/10.3109/17477166.2011.613671

Faigenbaum, A. D., Westcott, W. L., Loud, R. L., \& Long, C. (1999). The effects of different 
resistance training protocols on muscular strength and endurance development in children. Pediatrics, 104(1). https:/ / doi.org/10.1542/ peds.104.1.e5

Fajrina, H. N. (2015, November). Tingkat Kecanduan Gadget di Usia Dini Semakin Mengkhawatirkan.

CNN Indonesia. http:/ / www.cnnindonesia.com/teknologi/20151103093518-185-89078/tingkatkecanduan-gadget-di-usia-dini-semakin-mengkhawatirkan/

Fjørtoft, I. (2004). Landscape as Playscape: The Effects of Natural Environments on Children's Play and Motor Development. Children, Youth and Environment, 14(2), 21-44. http://www.colorado.edu/journals/cye/

$\mathrm{Hu}$, B. Y., Li, K., De Marco, A., \& Chen, Y. (2015). Examining the Quality of Outdoor Play in Chinese Kindergartens. International Journal of Early Childhood, 47(1), 53-77. https:/ / doi.org/10.1007/s13158-014-0114-9

Lestari, I., \& Ratnaningsih, T. (2016). The Effects of Modified Games on the Development of Gross Motor Skill in Preschoolers. International Journal of Evaluation and Research in Education (IJERE), 5(3), 216. https://doi.org/10.11591/ijere.v5i3.4542

Lovasi, G. S., Jacobson, J. S., Quinn, J. W., Neckerman, K. M., Ashby-Thompson, M. N., \& Rundle, A. (2011). Is the environment near home and school associated with physical activity and adiposity of urban preschool children? Journal of Urban Health, 88(6), 11431157. https:/ / doi.org/10.1007/s11524-011-9604-3

M. Fadlilah. (2014). Edutainment Pendidikan Anak Usia Dini. In Edutainment Pendidikan Anak Usia Dini. Pustaka Belajar.

Masnipal. (2018). Menjadi Guru PAUD Profesional. In Menjadi Guru PAUD Profesional (p. 400). Elex Media Komputindo.

Morrison, K. M., Cairney, J., Eisenmann, J., Pfeiffer, K., \& Gould, D. (2018). Associations of Body Mass Index, Motor Performance, and Perceived Athletic Competence with Physical Activity in Normal Weight and Overweight Children. Journal of Obesity, 2018. https:/ / doi.org/10.1155/2018/3598321

Mutiah, D. (2010). Psikologi Bermain Anak Usia Dini (Pertama). Prenada Media Group.

Ramdani, L. A., \& Azizah, N. (2019). Permainan Outbound untuk Perkembangan Motorik Kasar Anak Usia Dini. Jurnal Obsesi: Jurnal Pendidikan Anak Usia Dini, 4(1), 494. https:// doi.org/10.31004/obsesi.v4i1.407

Santrock, J. (2007). Perkembangan Anak: Jilid 1 (edisi kesebelas) (Kesebelas). Erlangga.

Serpentino, C. (2011). "The moving body": A sustainable project to improve children's physical activity at kindergarten. International Journal of Pediatric Obesity, 6(SUPPL. 2), 60-62. https://doi.org/10.3109/17477166.2011.613680

Story, M., Kaphingst, K. M., \& French, S. (2006). The role of child care settings in obesity prevention. In Future of Children (Vol. 16, Issue 1, pp. 143-168). https:// doi.org/10.1353/foc.2006.0010

Sugiyono. (2019). Metode Penelitian Kuantitatif, Kualitatif dan RED (kedua). Penerbit Alfabet Bandung.

Sunarsih, S., \& Dkk. (2007). Pendidikan Jasmani, Olahraga dan Kesehatan Penjas Orkes SD VI. Penerbit Erlangga.

Tandon, P., Hassairi, N., Soderberg, J., \& Joseph, G. (2020). The relationship of gross motor and physical activity environments in child care settings with early learning outcomes. Early Child Development and Care, 190(4), 570-579. https:// doi.org/10.1080/03004430.2018.1485670

Veldman, S. L. C., Jones, R. A., \& Okely, A. D. (2016). Efficacy of gross motor skill interventions in young children: an updated systematic review. BMJ Open Sport $\mathcal{E}$ Exercise Medicine, 2(1), e000067. https://doi.org/10.1136/bmjsem-2015-000067 